Article

\title{
Analysis of Ownership Data from Consolidated Land Threatened by Water Erosion in the Vlára Basin, Slovakia
}

\author{
Alexandra Pagáč Mokrá ${ }^{1}$, Jakub Pagáč ${ }^{2}$, Zlatica Muchová ${ }^{1, *(\mathbb{D})}$ and František Petrovič ${ }^{3}$ (i) \\ 1 Department of Landscape Planning and Land Consolidation, Faculty of Horticulture and Landscape \\ Engineering, Slovak University of Agriculture, Hospodárska 7, 94976 Nitra, Slovakia; \\ alexandra.mokra@gmail.com \\ 2 AgroBioTech Research Centre SUA in Nitra, Slovak University of Agriculture, Trieda A. Hlinku 2, \\ 94976 Nitra, Slovakia; jakub.pagac@uniag.sk \\ 3 Department of Ecology and Environmental Sciences, Faculty of Natural Sciences, University of Constantinus \\ the Philosopher in Nitra, Trieda A. Hlinku 1, 94901 Nitra, Slovakia; fpetrovic@ukf.sk \\ * Correspondence: zlatica.muchova@uniag.sk
}

Citation: Pagáč Mokrá, A.; Pagáč, J.; Muchová, Z.; Petrovič, F. Analysis of Ownership Data from Consolidated Land Threatened by Water Erosion in the Vlára Basin, Slovakia. Sustainability 2021, 13, 51.

https://dx.doi.org/doi:10.3390/ su13010051

Received: 4 November 2020 Accepted: 20 December 2020 Published: 23 December 2020

Publisher's Note: MDPI stays neutral with regard to jurisdictional claims in published maps and institutional affiliations.

Copyright: () 2020 by the authors. Licensee MDPI, Basel, Switzerland. This article is an open access article distributed under the terms and conditions of the Creative Commons Attribution (CC BY) license (https: / / creativecommons.org/ licenses/by/4.0/).

\begin{abstract}
Water erosion is a phenomenon that significantly damages agricultural land. The current land fragmentation in Slovakia and the complete ambiguity of who owns it leads to a lack of responsibility to care for the land in its current condition, which could affect its sustainability in the future. The reason so much soil has eroded is obvious when looking at current land management, with large fields, a lack of windbreaks between them, and no barriers to prevent soil runoff. Land consolidation might be the solution. This paper seeks to evaluate redistributed land and, based on modeling by the Universal Soil Loss Equation (USLE) method, to assess the degree of soil erosion risk. Ownership data provided information on how many owners and what amount of area to consider, while taking into account new conditions regarding water erosion. The results indicate that 2488 plots of 1607 owners which represent $12 \%$ of the model area are still endangered by water erosion, even after the completion of the land consolidation project. The results also presented a way of evaluating the territory and aims to trigger a discussion regarding an unambiguous definition of responsibility in the relationship between owner and user.
\end{abstract}

Keywords: water erosion; erosion threat to the soil; land fragmentation; land consolidation

\section{Introduction}

Soil erosion caused by water is one of the most widespread causes of soil degradation, and not just in Europe. Many authors [1,2] have written about the complete stripping of topsoil, what they consider to be a serious environmental, economic, and social problem. Only a few hundredths of a mm of new soil is created each year $[3,4]$ and, in just a few years, all of the soil can be completely eroded away. Because of the very low rate of soil formation, annual losses greater than $1 \mathrm{t}$ per ha can be considered irreversible within 50-100 years [5]. Erosion can be described as the mechanical action of moving water, wind, and other destructive forces removing the soil and transferring it elsewhere [6,7]. Soil erosion impacts all types of landscape. In most European countries, the mean erosion rate for agricultural land is greater than in forests [8].

From an agricultural perspective, soil erosion refers to the stripping of a field's surface layer by the natural physical forces of water and wind, or by forces generated by agricultural activities $[5,6]$. When the topsoil layer is shallow, all of the natural agricultural land can be lost. But if it is deeper, the loss of topsoil is often not visible, yet nonetheless potentially quite harmful. The main cause of soil erosion is detrimental agricultural practices [9] and ever-expanding development of agricultural land as urban areas grow [10]. Even climate change is accelerating the degradation of soil [11,12].

Universal Soil Loss Equation (USLE) [13] predicts the long-term average annual rate of erosion on a field slope based on rainfall pattern (rainfall erosivity factor " $R$ "), soil type 
(soil erodibility factor " $\mathrm{K}$ "), crop system (cover management factor " $\mathrm{C}$ "), and erosion control practices (effectiveness against erosion factor "P"). Discussions and limitations in topographic factors have led to revision of the equation. The Revised Universal Soil Loss Equation (RUSLE) has become [14] the most common method for estimating mean annual soil loss. RUSLE is better adaptable to disintegration under new conditions and provides more profitable results than USLE [15]. The Erosion Potential Method (EPM) estimates water erosion in hydrographical river basins, taking into account topography, climate, land use, and the type of soil [16]. EPM is applied across the world and, until recently, had been tailored to edaphoclimatic conditions found in Brazil [17,18]. The Modified Universal Soil Loss Equation (MUSLE) is a method commonly used because of the easy availability of data and MUSLE's production of meaningful results in agricultural land and reservoirs $[19,20]$. A review of soil erosion modelling can be found in the paper by Alewell et al. [21].

According to Eurostat [22], the annual rate of water erosion in Europe's agricultural land, forests, and semi-natural areas averaged around $2.5 \mathrm{t}$ per ha in 2016, while the annual mean rate of water erosion in agricultural areas and permanent grasslands in Europe was $3.4 \mathrm{t}$ per ha. Within the European Union (EU), the countries with the highest erosion rates in agricultural areas and natural grasslands are Italy, Portugal, France, Germany, and Sweden [22] (Figure 1).

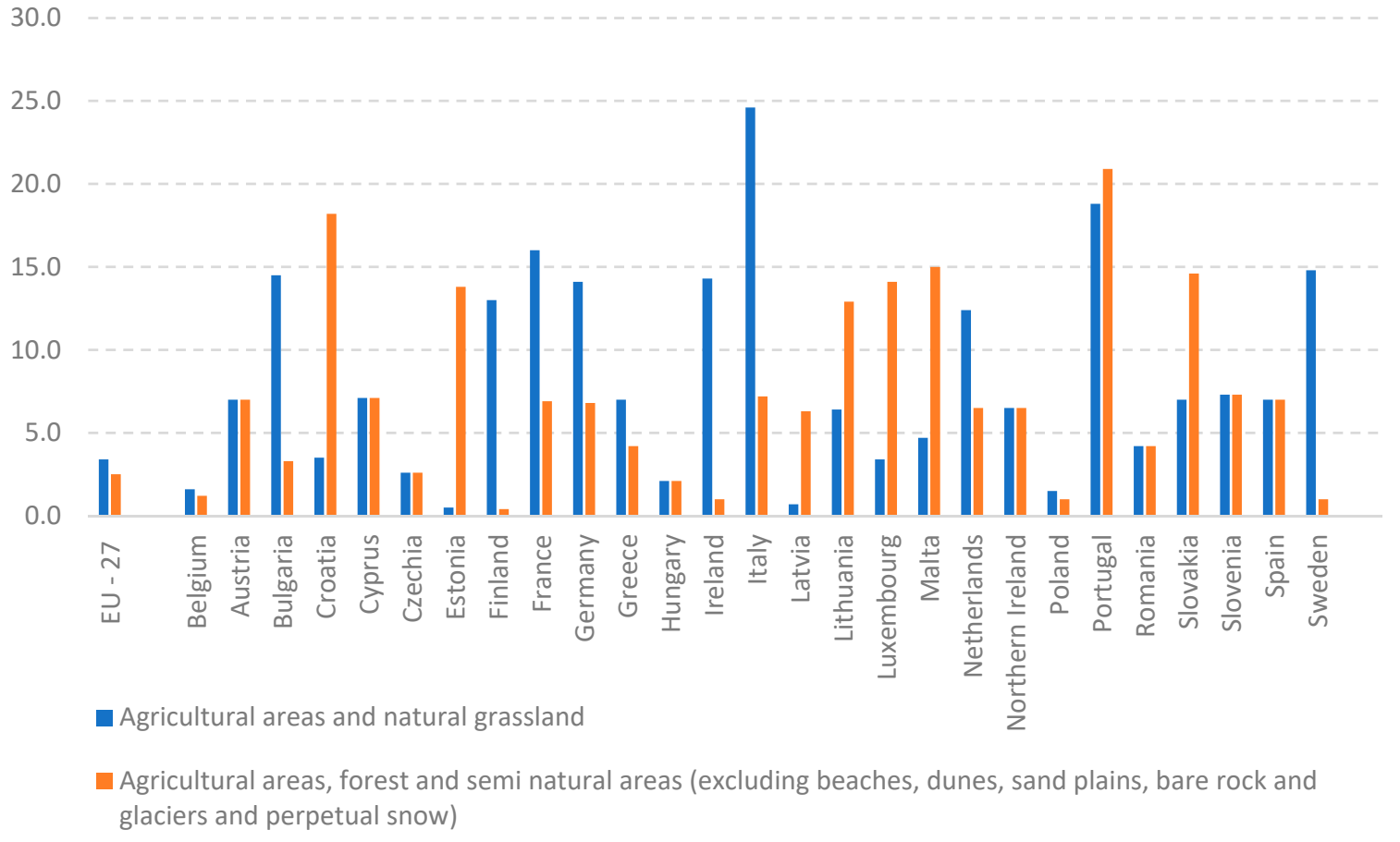

Figure 1. Estimated mean soil erosion rates in member states of European Union, 2016 [22].

The Soil Science and Conservation Research Institute (SSCRI) estimate that erosion will cost Slovakia annually $39.15 \%$ of its current agricultural land or 940,263 ha [23]. This is an enormous amount of land which, in particular, is intensively cultivated on a large scale. The eroded soil usually ends up in rivers and streams and is then transferred to reservoirs, where it settles $[24,25]$. The solution could be incorporated into a combination of organisational, agro-engineering, biological, and technical measures. Organisational measures include land delimitation, crop dispersion to combat erosion, and a proper determination of the size, shape, and arrangement of the land. Agro-engineering measures include contour farming and protecting the soil through no-till farming, mulching, subsoiling, stubble cleaning, and keeping any agricultural engineering to a minimum. Biological measures are 
strip cropping, stabilising the strips, anti-erosion sowing, planting grass, and reforestation to protect the soil. Technical measures are ditches and terrace farming to stop erosion [26].

Act 220/2004 as amended (legislative document defining the limiting values of soil loss due to erosion in the conditions of Slovakia) [27] makes the landowners, or the tenants to whom they lease the land and thereby transfer their obligations, responsible for instituting appropriate and correct agricultural practices. Yet the question remains why visible signs of erosion-furrows, washouts and rivulets-are still encountered despite these clearly defined responsibilities (Figure 2).

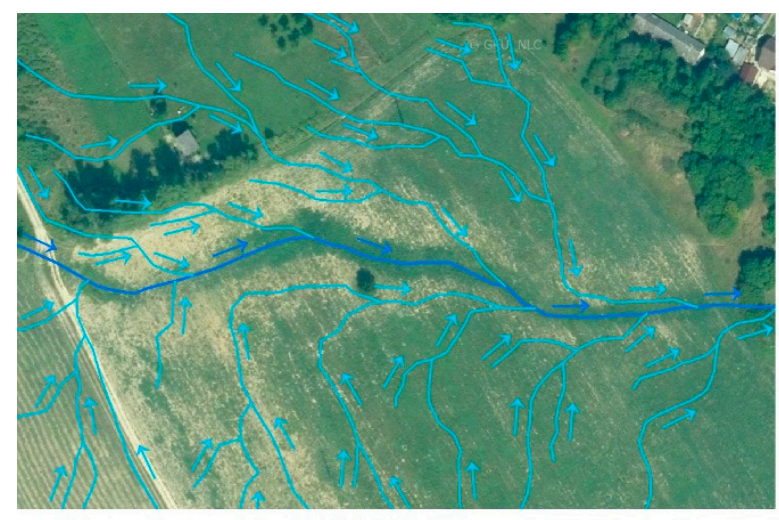

(a)

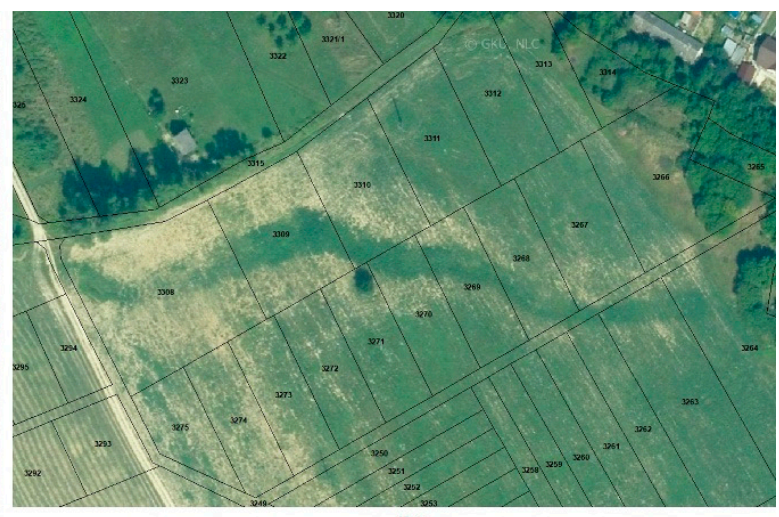

(b)

Figure 2. Erosion observed in the studied area (a) Orthophoto map and the erosion details with arrows (@ Eurosense, s.r.o. and GEODIS Slovakia, s.r.o.); (b) Overlay of orthophoto and land register maps after land reparcelling (ZBGIS).

The entire situation is complicated especially by Slovakia's huge fragmentation of land ownership [28]. Large land users dominate the land management and the possibilities of landowners to influence it towards a more environmentally-friendly ways are limited as well as eventual control and assessment of implementation of required measures. [29]. On average, 11 people own a single plot of land. An owner has a share in 22 land parcels, on average. There are over 100 million registered co-owners [30]. Fragmented land holding is defined as when a landholding or farm consists of a number of spatially distributed, small-area plots irregularly shaped and whose property boundaries are unclear [31]. Such fragmentation is widespread throughout Europe and agriculture takes place on such fragmented useful land. In 2010, the average size of a farm in Europe was 14.1 ha, but in countries such as Denmark and the United Kingdom this figure was over 60 ha. Italy has extensive fragmentation with farms averaging 7.9 ha in size, more than what had been recorded for agricultural land in Slovenia (6.5 ha), Croatia (5.6 ha), Greece (4.8 ha), Romania (3.4 ha), and Cyprus (3.0 ha), the lowest among all $28 \mathrm{EU}$ states [32].

Several European countries have redistributed land in order to eliminate certain types of fragmentation. This was done to a large degree in Austria [33], Poland [34], Estonia [35], Germany [36], Cyprus [37], Slovenia [38], Norway [39], Denmark [40], and Finland [41]. Interest in reparcelling and consolidating land has risen in all countries for the same reasons, such as to redistribute property without changing its ownership so that owners exploit it appropriately [42].

To date, Slovakia has redistributed land in 431 of the country's 3559 cadastral districts. Currently, there are 3103 cadastral districts remaining where land needs to be consolidated and the government should be embarking over a 30-year period to reparcel each year the land in 120 cadastral districts [43]. The land redistribution projects do not only serve to consolidate fragmented land ownership, but their purpose is to create a proposal for a system of measures, including preventing soil degradation. In this article, the authors try to link the fragmentation of land with the soil erosion problem. This contribution also attempts to point out the need to evaluate the feedback on the effectiveness of the proposed measures in land consolidation projects, as this has been ignored by Slovakia up till now. 
Because the land in the modelled area has already been consolidated, it is reasonable to assume that a minimum area would have been defined as endangered.

This paper attempts to assess erosion control measures in a land consolidation based on comparing soil erosion state before and after a project by classifying the plots into endangerment categories and by their ownership thus providing material for a discussion on position of land owner and tenant, role of the legislation, and the land ownership fragmentation in environmentally sensible land management.

\section{Materials and Methods}

\subsection{Characteristics of the Geographical Location}

The modelled area is the Vlára water catchment area (Figure 3), a tributary of the Váh River flowing from the Czech Republic whose source is below Kláštov Mountain (752.9 m) in the Vizovice Highlands. The Vlára runs in a southwest direction through the Vlára pass in the White Carpathian Mountains into Slovakia. The entire area is drained by the river and its tributary streams, the Vlárka, Branný, Čakanovský, Bradelský, Sietne, Hornosrniansky, and Kremnica. The Vlára passes through the cadastral district of Horné Srnie and empties into the Váh about one km from the village of Nemšová [44].

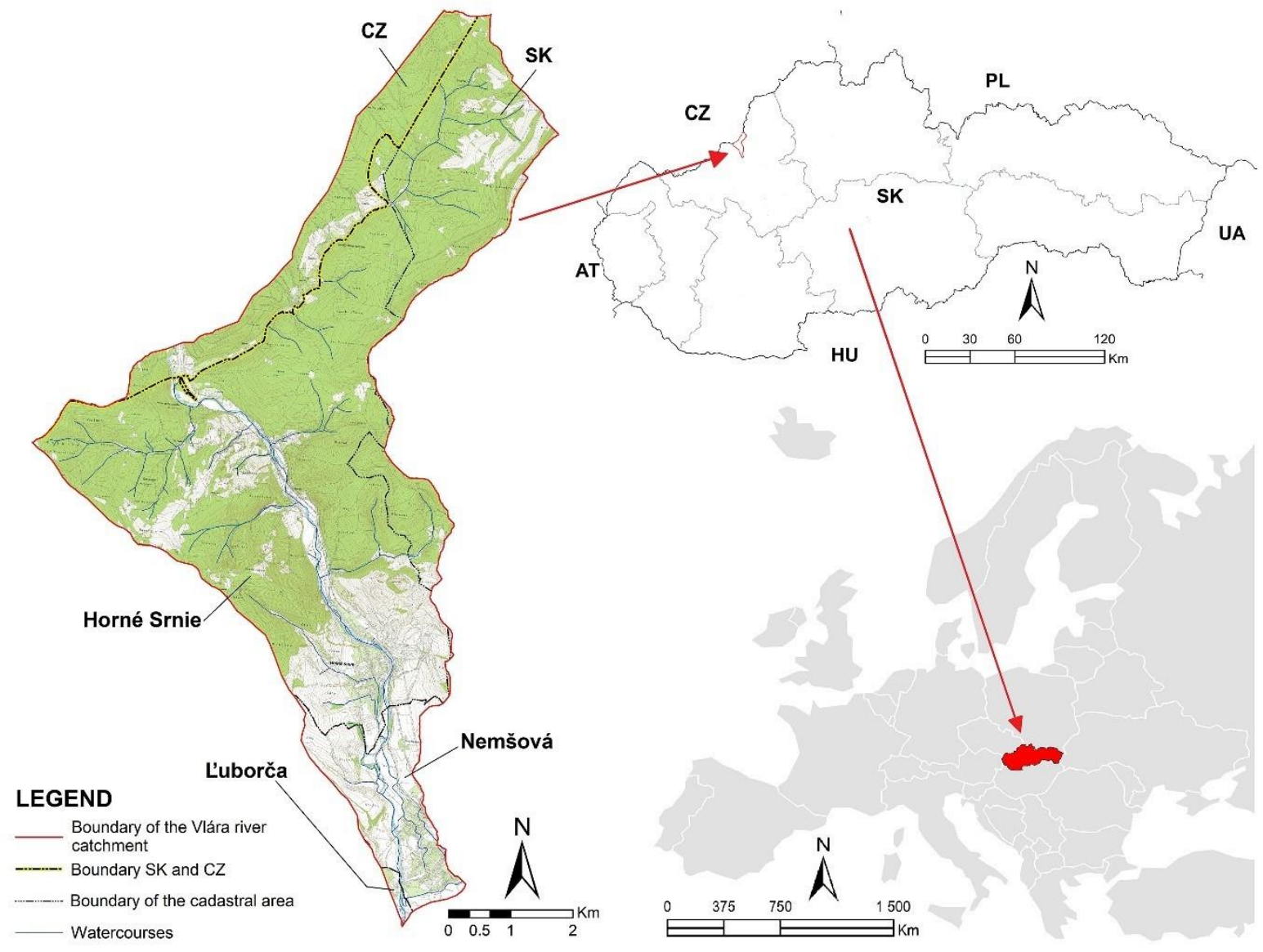

Figure 3. Broader relationships.

As of 31 December 2018, the Nemšová cadastral district's population stood at 6384 . The modelled area covers 389.60 ha out of a total of 3344 and is situated in the north-western part of Trenčín Region bordering the District of Ilava. It is located at the border of Moravia and Slovakia within the Váh River valley at the confluence with the Vlára and the Váh. Nemšová is divided into the former villages and new neighbourhoods of Nová Nemšová, L'uborča (the modelled area extends 18.06 ha therein), Kl'účové, and Trenčianska Závada. 
It is bordered to the north by the village of Horné Srnie, with an area of 2726 ha (the modelled area covers also 2555.96 ha thereof) and a population of 2750 as of 31 December 2018 [45]. It lies on the Slovakian side of the White Carpathians, at the mouth of the Vlára Pass in the central Považíe (Váh Valley) region. The catchment area is located within the geomorphologic Považské Podolie around the White Carpathians (Biele Karpaty) and also belongs to the Ilavská Kotlina and Bielokarpatské Podhorie. In terms of relief, the area is mostly rugged mountainous terrain, although the south is composed of the negative morphostructures found in the Pannonian Basin, i.e., relatively young, declining morphostructures with aggradation. There are fluvial and slope processes in the area, with both fluvial and deep erosion quite strong. The geological structure of the wider area is composed of Mesozoic, Neogene, and Quaternary soils. The rocks of the Klippen zone above the area feature a varied development of limestone, sandstones, claystones, and shale. The soil in the area is mainly composed of fluvizols, luvisols, stagnosols, and cambisols. Soil permeability is medium and soil retention capacity is medium to high. In terms of granularity, the soil is predominately sandy-loamy to loamy and characterised as slightly moist [46].

Land consolidation has taken place in the cadastral districts of Nemšová and Horné Srnie. Land in L'uborča was consolidated between 12 May 1993 and 14 September 2010, in Horné Srnie between 2 August 1993 and 14 February 2011, and in Nemšová itself between 20 August 1993 and 20 September 2010.

\subsection{Data Collection and Analysis}

The area was defined and the intensity of water erosion for the Vlára catchment area calculated from data in the updated map of certified soil-ecological units (in Slovak "BPEJ" for bonitované pôdno-ekologické jednotky) and the cadastral map for use of the area after the reparcelling and land improvement was registered (Figure 3).

It incorporates new communicating paths, anti-erosion barriers, and other environmental action taken (whose legal status has been registered without them having been necessarily implemented). Land consolidation design in the model area included just measures for construction of a road infrastructure needed to make the plots of land accessible, i.e., forest roads with total length of $6.61 \mathrm{~km}$ and field roads with total length of $36.27 \mathrm{~km}$.

The boundaries of the Vlára catchment area were defined from a digital elevation model (DEM) of the contour map at a scale of 1:10,000. To create the DEM (Figure 4a), the Topo to Raster interpolation method was used, with a resolution to two $\mathrm{m}$. Soil loss has been quantified by the universal soil loss equation, USLE, as adapted and required in Methodology no. 5/1992: Protection of agricultural soil against erosion [47] and modified for the geographic information system (GIS) environment in 2012 [48]. The USLE methodology is required by the Slovak legislation in the Decree no. 59/2013 Coll. [49] and the central portal on soil characteristics of the authoritative pedological institution in Slovakia-Soil Science and Conservation Research Institute (SSCRI) in Bratislava quantifies the loss of soil by water erosion using the USLE model (http:/ / www.podnemapy.sk/portal/verejnost/ erozia/vod/vod.aspx). The USLE, which contains six underlying factors, was used to analyse the threat of water erosion [13]. The rainfall factor $(R)$ of 14.21 was determined from ombrograph records [50] kept at the nearest station in Trenčín, which is located about $20 \mathrm{~km}$ from the observed area. The soil erodibility factor $(\mathrm{K})$ was derived from the BPEJ for individual soil types, expressed in a seven-digit BPEJ code with three- and four-digit codes for the main soil unit (HPJ for hlavná pôdna jednotka). K fluctuates between 0.20 and 0.70 (Figure 5a). The topographic factor "(LS)" is based on the incline and length of the slope [51]. It expresses the ratio of land loss per unit slope area to land loss per unit plot. The factor was calculated from relation (1)

$$
\mathrm{LS}=\mathrm{I}_{\mathrm{d}}^{0.5} \cdot\left(0.0138+0.0097 . \mathrm{s}+0.00138 . \mathrm{s}^{2}\right)
$$

where:

$\mathrm{I}_{\mathrm{d}}$-uninterrupted slope length $[\mathrm{m}]$ 
s-slope gradient [\%].

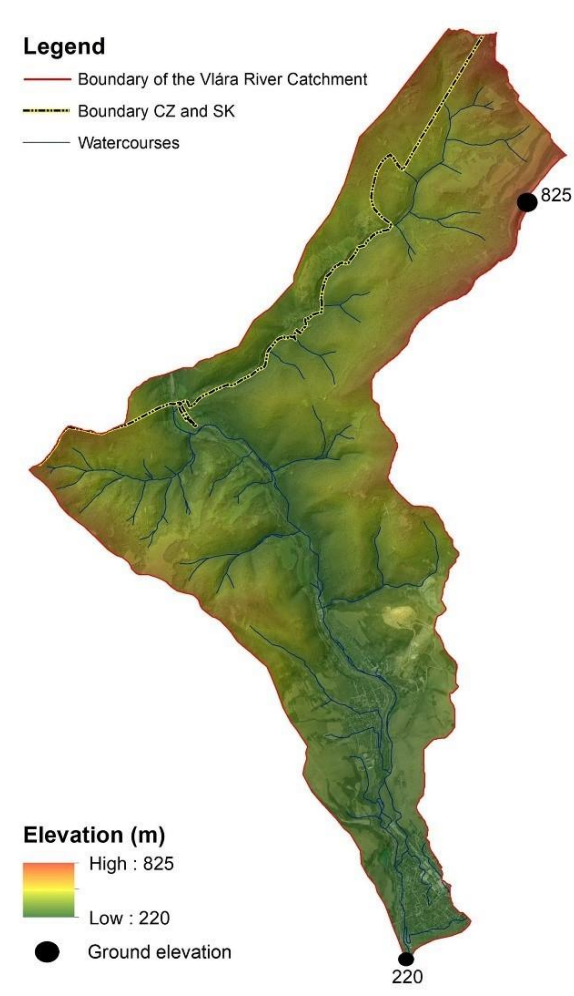

(a)

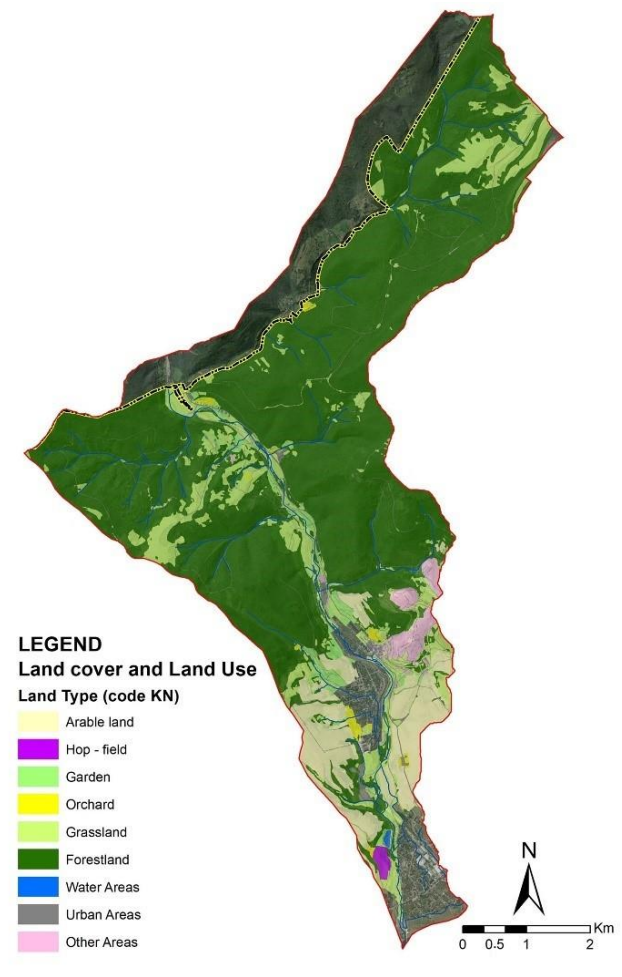

(b)

Figure 4. (a) Digital relief model; (b) current use of the landscape.

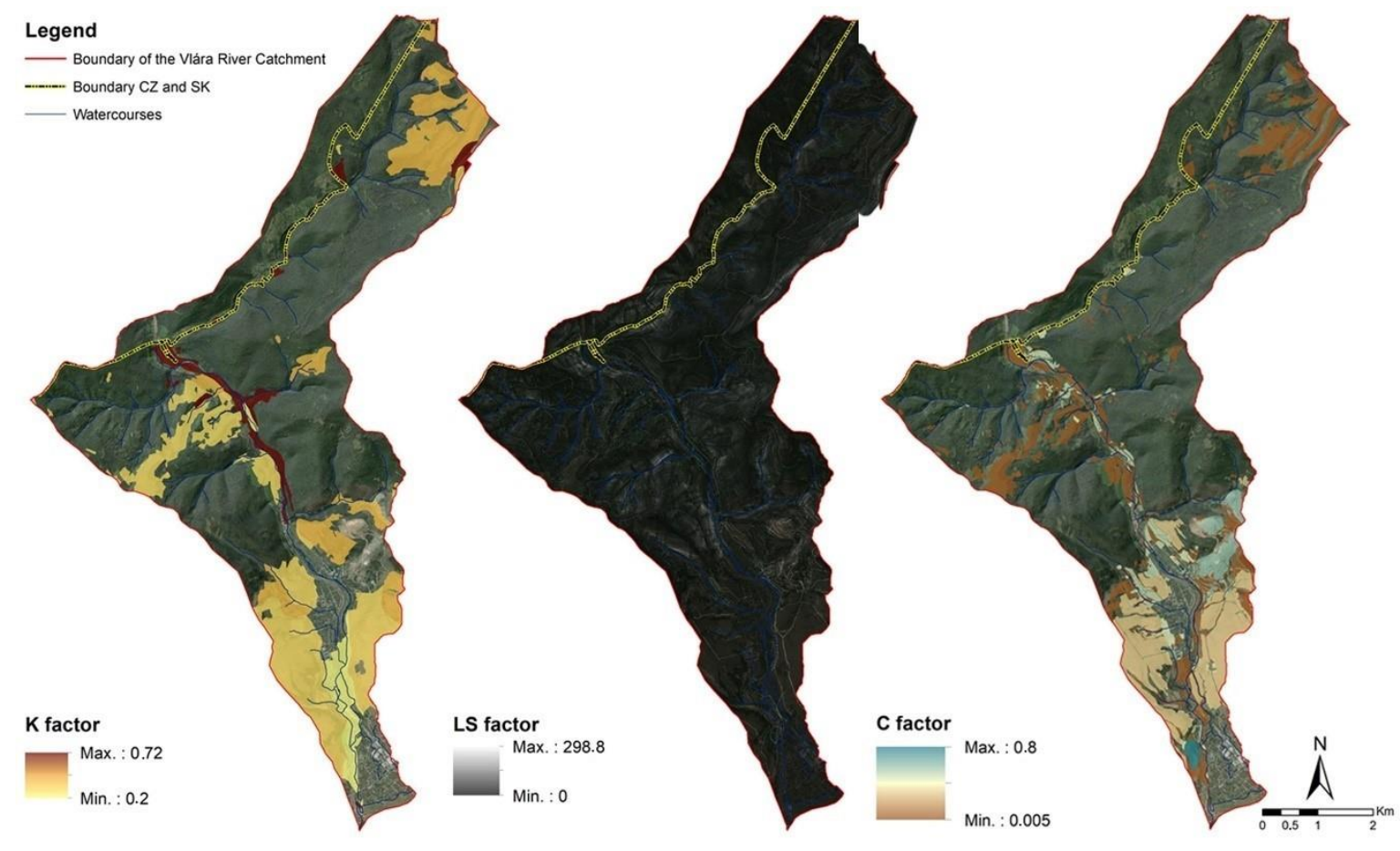

(a)

(b)

(c)

Figure 5. (a) Factor K, (b) Factor LS, (c) Factor C. 
Barriers already existing to transform surface runoff to subsurface runoff were also taken into account to calculate LS. The topographic factor fluctuates at a range between 0 and 298 (Figure 5b). The crop management factor (C) for the landscape's different elements of land use after reparcelling and any improvement (Figure 5c) was simplified for the type of land that was processed [52]. These values were determined to be 0.29 for arable land, 0.005 for grassland, 0.45 for non-forest woody vegetation, 0.5 for ordinary gardens, 0.8 for hop gardens, and 0.45 for orchards (Figure $4 \mathrm{~b}$ ). A value of 1 was chosen for erosion control practices $(\mathrm{P})$ because detailed information about anti-erosion action taken in the area was not available (land users are not legally obliged to keep consistent records of erosion control practices on the land they manage).

Permissible soil erosion limits for water erosion were defined in accordance with either Act 220/2004 [27] or STN 754501 [53]. In both methods, the depth of the soil is critical for determining permissible soil erosion. The standard's stricter, more stringent categories were used. The permissible values for different soil depth categories were shallow soil (to $30 \mathrm{~cm})$ : one tonne per ha annually $\left(1\right.$ t.ha $^{-1} \cdot$ year $\left.^{-1}\right)$; medium-deep soil $(30-60 \mathrm{~cm})$ : four $\mathrm{t}$ per ha annually $\left(4 \mathrm{t} \cdot \mathrm{ha}^{-1}\right.$.year $\left.{ }^{-1}\right)$; and deep soil (over $60 \mathrm{~cm}$ ): ten $\mathrm{t}$ per ha annually (10 t.ha ${ }^{-1} \cdot$ year $^{-1}$ ). The ratio between calculated actual intensity (with the $C$ factor) and potential intensity (omitted $C$ factor) and permissible erosion expresses the degree of soil erosion risk (SER) in five classes: not endangered or slightly endangered (under 1.00), moderately endangered (1.01-2.00), significantly endangered (2.01-7.00), very significantly endangered (7.01-28.00), and catastrophically endangered (over 28.00) (Table 1). SER was determined from calculated actual water erosion intensity in relation to permissible erosion expressed according to the stricter standards given in the STN 754501 [53].

Table 1. Degree of soil endangered by erosion.

\begin{tabular}{|c|c|c|c|}
\hline $\begin{array}{l}\text { Soil Erosion } \\
\text { Risk (SER) }\end{array}$ & $\begin{array}{c}\text { Name of Soil } \\
\text { Endangered by Erosion }\end{array}$ & Land Area (ha) & Land Area (\%) \\
\hline$<1.00$ & $\begin{array}{l}\text { Unaffected or slightly } \\
\text { endangered }\end{array}$ & 592.03 & 87.50 \\
\hline $1.01-2.00$ & Moderately endangered & 18.57 & 2.74 \\
\hline $2.01-7.00$ & Significantly endangered & 24.36 & 3.60 \\
\hline $7.01-28.00$ & $\begin{array}{l}\text { Very significantly } \\
\text { endangered }\end{array}$ & 35.65 & 5.27 \\
\hline$>28.01$ & $\begin{array}{l}\text { Catastrophically } \\
\text { endangered }\end{array}$ & 5.92 & 0.88 \\
\hline
\end{tabular}

The USLE was then integrated into a geographic information system (GIS). The factors influencing water erosion are expressed in maps created from an existing database. Landowner data (map and description) were obtained from ZBGIS [54], (available at https: / zbgis.skgeodesy.sk/, retrieved on 15 January 2020), where an analysis was made of ownership type (state, municipal, church, private), plot area in ha and the number of owners. Each owner has its own identification number in the Land Register's descriptive data. If the same person or entity owns more than one plot, then the identification number is repeated.

Property can be owned by a single person or entity or jointly owned with others. The geometric parameters of the property boundaries were overlaid in the ArcGIS 10.2.2 (www.esri.com) software environment, using the Zonal Statistic function with the degree of soil erosion risk. The result was a layer (Figure 6) that included data about the owners, the soil erosion risk by the selected category (indicated as 1-5 from least endangered to most endangered) and the area in ha. The data were divided into five categories based on the degree of erosion risk, while the holdings were classified by land area into categories, too. 


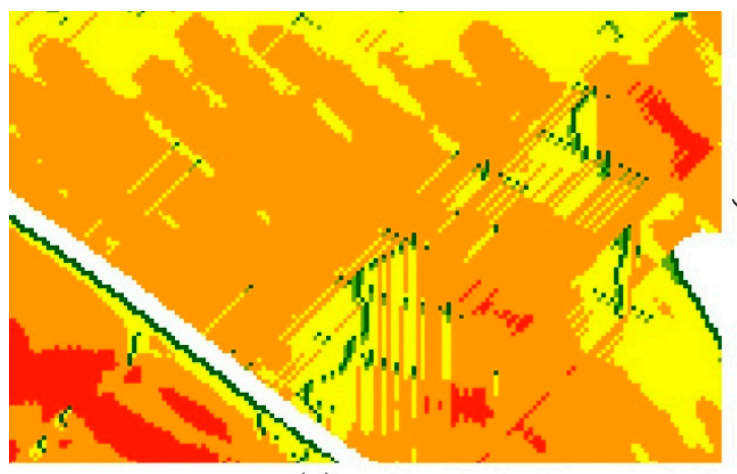

(a)

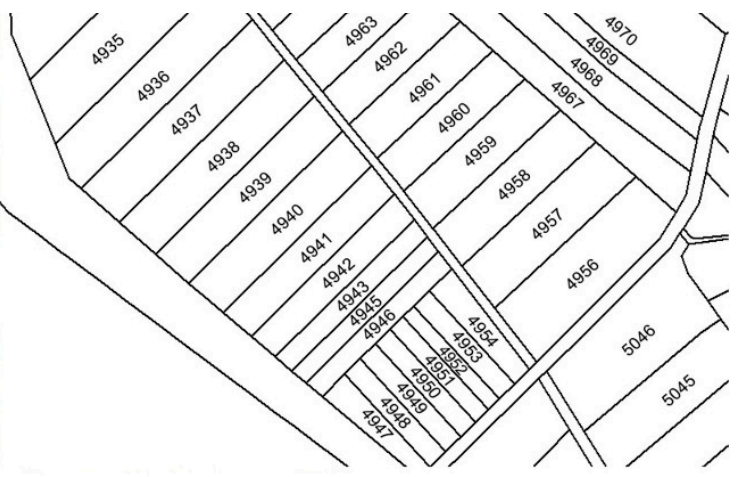

(b)

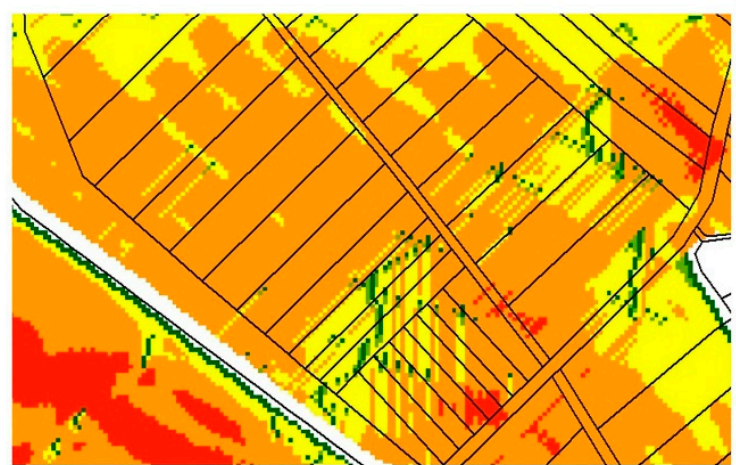

Soil erosion risk (SER)

D. Property boundaries

Not endangered or slightly endangered $(<1.00)$ Moderately endangered (1.01-2.00)

Significantly endangered (2.01-7.00)

Very significantly endangered (7.01-28.00)

Catastrophically endangered $(>28.01)$

(c)

Figure 6. (a) SER, (b) Landowners, (c) SER Overlap + Property Boundaries.

\section{Results}

The current land use map indicates that forest land is the most common land use with $72 \%$ of the modelled area. The remaining percentages are permanent grassland$13 \%$, arable land $-7 \%$, built-up land $-3 \%$, other lands and gardens $-2 \%$, water, orchards, and hop gardens-1\%. The USLE was used to determine potential and calculated real erosion runoff (Figure 7). Soil erosion was classified into four categories: less than 10; 101-150; 151-200; greater than 200 (t. ha ${ }^{-1}$. year ${ }^{-1}$ ).

Table 2. Calculated water erosion intensity in the modelled catchment area.

\begin{tabular}{ccccc}
\hline $\begin{array}{c}\text { Category Soil } \\
\text { Endangered }\end{array}$ & $\begin{array}{c}\text { Mean Value Loss } \\
\text { of Soil (t. ha }^{-\mathbf{1}} \\
\text { Year } \mathbf{- 1})\end{array}$ & $\begin{array}{c}\text { Land } \\
\text { Area (ha) }\end{array}$ & $\begin{array}{c}\text { Calculated } \\
\text { Loss of Soil } \\
\text { (t. Year } \mathbf{- 1}^{-1}\end{array}$ & $\begin{array}{c}\text { Calculated Loss } \\
\text { of Soil (\%) }\end{array}$ \\
\hline$<1.00$ & 1.03 & 592.03 & 609.65 & 36.13 \\
$1.01-2.00$ & 8.03 & 18.57 & 149.06 & 8.83 \\
$2.01-7.00$ & 7.08 & 24.36 & 172.46 & 10.22 \\
$7.01-28.00$ & 14.25 & 35.65 & 508.13 & 30.12 \\
$>28.01$ & 41.87 & 5.92 & 247.89 & 14.69 \\
Together & & & 1687.18 & 100 \\
\hline
\end{tabular}

There were 3696 holdings in the areas where the degree of soil endangered by erosion was determined.

Table 3 shows land is predominately in state hands followed by private hands. The total area is spread among 14 groups according to ownership (private, state, municipal, Vlára Agricultural Cooperative, church, Slovenská správa ciest (Slovak Road Authority), Spoločenstvo bývalých urbárnikov a lesomajitel'ov (Community of Former Landowners and Foresters), SPP_distribúcia, a.s., Lesy České republiky (Czech Republic Forests), Lesy Slovenskej republiky (Slovak Republic Forests), Občianska záložňa v Brumove 
(Brumov Civic Reservation), Pastevní Družstvo Sidónie (Sidónie Pasture Cooperative), RST GLOB s.r.o., and Slovenský vodohospodársky podnik, š. p.).

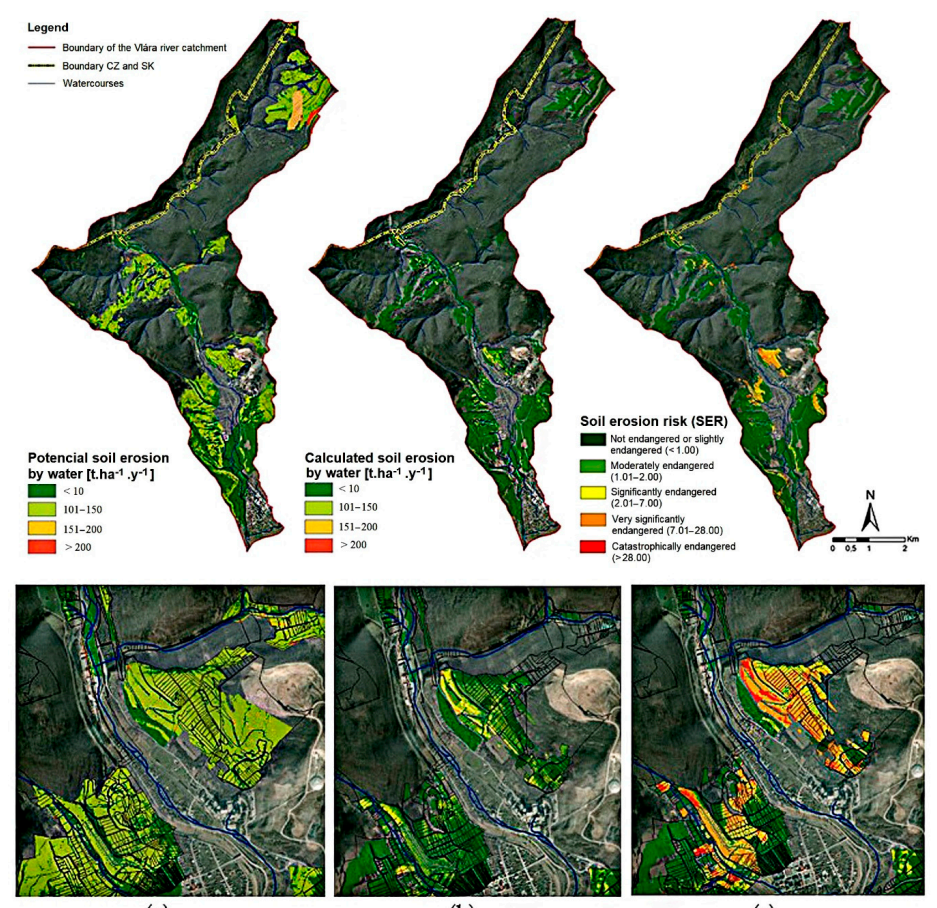

(a)

(b)

(c)

Figure 7. (Water erosion intensity: a) potential intensity; (b) calculated actual intensity, (c) degree of soil erosion risk (shown in detail with property boundaries).

Table 3. Summarised areas by ownership type on erosion endangered soil.

\begin{tabular}{|c|c|c|c|c|c|c|}
\hline \multirow{2}{*}{ Ownership } & \multicolumn{2}{|c|}{ Nemšová } & \multicolumn{2}{|c|}{ L'uborča } & \multicolumn{2}{|c|}{ Horné Srnie } \\
\hline & ha & $\%$ & ha & $\%$ & ha & $\%$ \\
\hline Municipal & 17.21 & 6.35 & 0.57 & 5.45 & 27.90 & 2.14 \\
\hline State & 35.19 & 12.98 & 2.93 & 28.01 & 584.50 & 44.83 \\
\hline Church & 9.45 & 3.49 & 1.07 & 10.23 & 3.85 & 0.29 \\
\hline Private & 127.21 & 46.94 & 1.24 & 11.85 & 461.37 & 35.39 \\
\hline Vlára Agricultural Cooperative & 1.30 & 0.48 & - & - & 0.74 & 0.06 \\
\hline Slovak Road Authority & 0.44 & 0.16 & - & - & - & - \\
\hline $\begin{array}{c}\text { Community of Former Landowners } \\
\text { and Foresters }\end{array}$ & 41.37 & 15.26 & - & - & - & - \\
\hline SPP—distribúcia, a. s. & 0.06 & 0.02 & - & - & - & - \\
\hline Západoslovenská distribúcia, a. s. & 0.01 & 0.005 & - & - & - & - \\
\hline Czech Republic Forests & - & - & - & - & 19.61 & 1.50 \\
\hline Slovak Republic Forests & - & - & - & - & 0.01 & 0.001 \\
\hline Brumov Civic Reservation & - & - & - & - & 6.12 & 0.47 \\
\hline Sidónie Pasture Cooperative & - & - & - & - & 0.40 & 0.03 \\
\hline RST GLOB s. r. o. & - & - & - & - & 1.14 & 0.09 \\
\hline $\begin{array}{l}\text { Slovenský vodohospodársky } \\
\text { podnik, š. p. }\end{array}$ & 1.84 & 0.68 & - & - & - & - \\
\hline
\end{tabular}

Ownership was divided into three groups covering the number of owners, land area, and number of plots (Table 4). These ownership groups are classified into categories based on the five SER classes. Private ownership is the most common type, with 1607 holdings on 589.82 ha covering 2488 plots. Other ownership types are state-owned and municipallyowned land. All five SER categories can be found in the area, with the most, 1022.05 ha or $64.48 \%$ of the total area, classified in the first, lowest category (unaffected or slightly 
endangered); 192.61 ha or $12.15 \%$ of the total studied area fall into SER Category 4 (very significantly endangered) or Category 5 (catastrophically endangered). All of the L'uborča cadastral district's soil is classified in SER Categories 1 or 2, while no soil in the cadastral district of Nemšová was placed in SER Category 5. The most endangered parcels (16 plots) are found in the cadastral district of Horné Srnie, all of which are in Category 5. The steep sloping and rugged terrain here is the reason all the catastrophically endangered soil is situated at a single area, while the cadastral districts of Nemšová and L'uborča lie on flatter terrain along the Vlára River.

Table 4. Overview of ownership by SER in the cadastral districts of Nemšová, L'uborča and Horné Srnie.

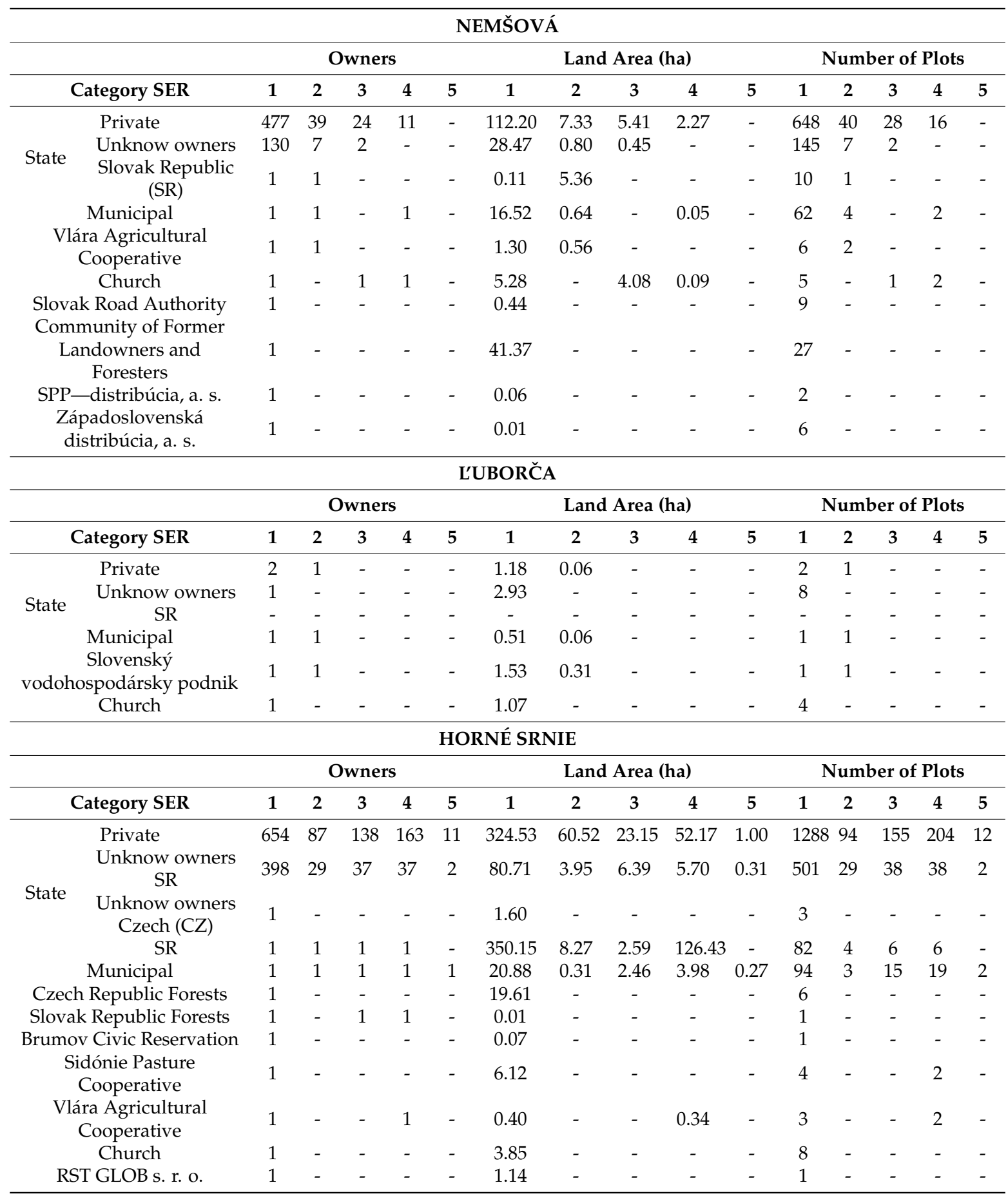


It is clear from Table 5 that 229 holdings out of the total number in the area have soil significantly or catastrophically endangered by water erosion. There are 14 holdings in the cadastral district of Horné Srnie whose soil is catastrophically in danger of water erosion.

Table 5. Number of owners falling into the categories of erosion endangered soil.

\begin{tabular}{cccc}
\hline SER & Nemšová & L'uborča & Horné Srnie \\
\hline Unaffected or slightly & 615 & 12 & 1062 \\
endangered & 49 & 13 & 118 \\
Moderately endangered & 27 & & 177 \\
Significantly endangered & 13 & & 202 \\
Very significantly endangered & & 14 \\
Catastrophically endangered & & & \\
\hline
\end{tabular}

From the example of the model area, it is unfortunately clear that the new reorganization did not achieve the expected benefits of land consolidation related to the protection of the landscape from water erosion. Despite taking 42.88 ha of land for improvement measures, $12 \%$ of the area remained unresolved with regard to a significant erosion risk.

\section{Discussion}

The new road network project for the model area providing accessibility to land was designed incorrectly. Unfortunately, it did not take into account the erosion protection of the area in most cases. The placement of roads has been suboptimal; incorrect location on the slopes did not interrupt the slope length, which should create, together with the anti-erosion ditch, a barrier to surface runoff. The state of endangered sites is mostly identical before and after land consolidation.

Two main problems have been identified:

- Errors, underestimation of land consolidation design and neglecting analytical work, which seems to be a serious problem in several projects analysed by the authors, plus weak, often none/neglected control by a state authority. This problem is easy to solve. Thorough control of the entire landscaping project and subsequent implementation of measures can be achieved by the country adopting a proper framework of functional land use according to the new plan of common measures and facilities for the protection and use of the territory.

- A more serious problem is that even in the cases of correct optimization of the area in the land consolidation project, practically (in terms of land management) nothing will change, many times. Most of the landlords, as a rule, leave their land in use by the original tenants, who continue to handle the area in the usual way, disregarding the environmental measures. They manage small plots of individual owners in merged land blocks, which is the reason for the continuation of degradation processes.

This study also tries to point out that land consolidation could be a significant impulse to a change in the management of countryside towards limiting the consequences of degradation processes. According to authors as [55], the quantity and quality of green spaces examined on the basis of land-use change has shown a declining trend over the last forty years. Soil degradation increases [56] and according to Sumfleth et al. [57] it is necessary to start a complex debate around land use change associated with a growing demand for biomass. Reducing crop diversity and homogenizing land use is a cause of increasing soil degradation [58]. The tolerated rate of erosion is defined by the sustainability of natural resources, and the soil lost has to be lower than what is naturally formed. [59] The most significant problem not discussed in the literature is the soil that is carried away from property holdings registered to one owner to another's land. The soil elements move onward from one landholding to another until they finally reach the river. The soil elements transported in this way end up in water areas, turn into sediments, and reduce the permeability of watercourses and the volume capacity of water reservoirs. With correctly 
designed soil erosion management, there would be no washing of soil elements to the land of other owners or those would get trapped in buffer zones, eventually. Therefore, ownership of the drifting soil is not resolved. Soil ownership is based on the parcels geometrically drawn on the cadastre map and nothing changes on paper even after the soil erodes elsewhere. Opinion is shared that pricing topsoil is quite complicated [60]. The price of topsoil stripped from construction sites has been calculated at between $€ 8$ and $€ 15$ euros per cubic $\mathrm{m}$ (where the mean specific weight of the soil is $1450 \mathrm{~kg}$ ). In the modelled area, the average price of soil lost to erosion amounted to $€ 11.50$ per cubic $m$ or, at $1687.18 \mathrm{t}$ of soil lost per year, to a cost of $€ 13,381.11$.

According to Schwilch et al. [61], the land management affects ecological processes, which in turn affect the kinds of benefits that people derive from land. The Food and Agriculture Organisation of the United Nations (FAO) [62] sees land ownership systems, as well as tenure and business, to have the most significance in protecting soil. Soil degradation has increased especially when users consider the soil just a source of income and livelihood, or when there are inequalities in who owns the soil. This is often the case in countries where land protection laws are not well-developed. According to the authors Rapsomanikis [63], land degradation in Slovakia is the result of incorrectly set agricultural legislation. Landowners could be allowed to charge a sufficiently high rent to compensate for the soil and nutrients therein that are lost, unless the lease mentions the condition of the farm when it ceases to operate [64]. Legal documents on leases with a precise definition of the principles of soil protection against degradation could be the solution. In the conditions of Slovakia, the lease agreement does not usually mention the clause on a careful management of land. Soil protection is given by legislation, which is, however, often set very benevolently, e.g., the water erosion limits. Relevant studies, e.g., [65], show that land management is also in the hands of legislators in order to promote land rights and land use policies. Results of [65], according to which tenure insecurity may lead to degradation of soils, are supported by our experience. In countries with a high ratio of rented land, it is therefore particularly desirable to promote long-term leases as opposed to the short-term ones, and set agro environmental standards. The study of Azadi et al. [64] suggest that one possible approach to mitigate the land degradation is collection/evaluation of feedback on effects of soil protection practices and related incentives before implementing new policies. An interesting insight reported by Uchiyama and Kohsaka [66] claims that the protection of the landscape, in a time of pandemic, is beginning to influence national policies that need to further address green areas (including agricultural lands) and healthy landscapes. Degraded landscapes endanger the sustainability of a territory and are also detrimental to health and well-being.

The problem in the solution based on a stricter setting of environmental measures in lease agreements lies in the current position of the owner of agricultural land in the conditions of Slovakia. Long term unresolved fragmented land ownership and lease agreements result in continuing formation of passive owners. Owners know what they own, but they do not know exactly where [31]. As a rule, they let their small shares scattered throughout the cadastral area to be used by tenants and are content with any fee provided. Only an owner with unambiguous and consolidated ownership on the map and in the field has the potential to go look at the land and evaluate its condition.

Mediation and education is needed to ensure effective and sustainable use of land that is not detrimental to those least able to make changes. Tenant farmers might not always farm in the best interests of the soil; however, it is still in their interest that they can continue to farm an area, albeit being handicapped by the short-term leases mentioned earlier.

\section{Conclusions}

The main benefit of land consolidation and reparcelling projects is to make the area optimally functional. The design of a multifunctional system for communications, environmental action, and to combat erosion is a condition for such projects to be successful. The outcome should be a landscape organised so new plots of land created from the reor- 
ganisation are accessible from roads and the soil is in no danger of erosion. The impact upon owners of whatever the project proposes is not examined here in greater detail. Even when a minimum number of owners start to exploit their own soil after the reparcelling of the land causes no sufficient need for the owners to have an interest in it. It remains in use by large agricultural holdings even after the land has been consolidated and rules govern such use, as was the case before land consolidation took place. The soil will continue to be degraded unless action is taken. Using the USLE method, 3696 holdings in the Vlára model basin have been evaluated for danger of erosion. The owner groups have been classified into five classes (SEOP). Privately owned land by 1607 people on 589.82 ha in 2488 plots, even after completion of the land consolidation project, on a total of $12 \%$ of the modeled area, still had signs of soil endangered by water erosion.

A land consolidation project has the potential to optimize the landscape, including incorporating a system of accumulation and collection measures for erosion control. But, agricultural holdings keep managing the land even after land consolidation in most cases and apply methods associated with a growing demand for biomass. Land ownership defragmentation with more environmentally conceived long-term tenure might be a very important factor in land degradation reduction if land-owners are not going to farm the land themselves.

Author Contributions: Conceptualization, A.P.M. and Z.M.; methodology, A.P.M., Z.M., and F.P.; formal analysis, A.P.M. and J.P.; data curation, A.P.M. and J.P.; writing, A.P.M., Z.M., and J.P.; visualization, A.P.M.; supervision, Z.M.; project administration, F.P.; funding acquisition, F.P. All authors have read and agreed to the published version of the manuscript.

Funding: This publication is the result of the project implementation: "Scientific support of climate change adaptation in agriculture and mitigation of soil degradation" (ITMS2014+ 313011W580) supported by the Integrated Infrastructure Operational Programme funded by the ERDF.

Institutional Review Board Statement: Not applicable.

Informed Consent Statement: Not applicable.

Data Availability Statement: Data used in this contribution are from public resouces cited in the article.

Conflicts of Interest: The authors declare no conflict of interest.

\section{References}

1. Wang, B.; Zheng, F.; Römkens, M.J.M.; Darboux, F. Soil erodibility for water erosion: A perspective and Chinese experiences. Geomorphology 2013, 187, 1-10. [CrossRef]

2. Gruver, J.B. Prediction, Prevention and Remediation of Soil Degradation by Water Erosion. Nat. Educ. Knowl. $2013,4,2$.

3. Antal, J. Soil Erosion Protection; Slovak University of Agriculture: Nitra, Slovakia, 2005. (In Slovak)

4. Midriak, R. Eroded Ruined Soils of Slovakia; Science and Research Centre-Institute of Landscape and Regional Research of Matej Bel University in Banská Bystrica: Banská Bystrica, Slovakia, 2010; p. 190. (In Slovak)

5. Chen, Z.; Wang, L.; Wei, A.; Gao, J.; Lu, Y.; Zhou, J. Land-use change from arable lands to orchards reduced soil erosion and increased nutrient loss in a small catchment. Sci. Total Environ. 2019, 648, 1097-1104. [CrossRef] [PubMed]

6. Borrelli, P.; Robinson, D.A.; Fleischer, L.R.; Lugato, E.; Ballabio, C.; Alewell, C.; Meusburger, K.; Modugno, S.; Schütt, B.; Ferro, V.; et al. An assessment of the global impact of 21st century land use change on soil erosion. Nat. Commun. 2017, 8 , 2013. [CrossRef]

7. Pena, B.S.; Abreu, M.M.; Magalhaes, M.R.; Cortez, N. Water erosion aspects of land degradation neutrality to landscape planning tools at national scale. Geoderma 2020, 363, 114093. [CrossRef]

8. Panagos, P.; Ballabio, C.; Poesen, J.; Lugato, E.; Scarpa, S.; Montanarella, L.; Borrelli, P. A Soil Erosion Indicator for Supporting Agricultural, Environmental and Climate Policies in the European Union. Remote Sens. 2020, 12, 1365. [CrossRef]

9. Covelli, C.; Cimorelli, L.; Pagliuca, D.N.; Molino, B.; Pianese, D. Assessment of Erosion in River Basins: A Distributed Model to Estimate the Sediment Production over Watersheds by a 3-Dimensional LS Factor in RUSLE Model. Hydrology 2020, 7, 13. [CrossRef]

10. Wei, L.; Luo, Y.; Wang, M.; Su, S.; Pi, J.; Li, G. Essential fragmentation metrics for agricultural policies: Linking landscape pattern, ecosystem service and land use management in urbanizing China. Agric. Syst. 2020, 182, 102833. [CrossRef]

11. Čimo, J.; Aydin, E.; Šinka, K.; Tárník, A.; Kišš, V.; Halaj, P.; Toková, L.; Kotuš, T. Change in the Length of the Vegetation Period of Tomato (Solanum lycopersicum L.), White Cabbage (Brassica oleracea L. var. capitata) and Carrot (Daucus carota L.) Due to Climate Change in Slovakia. Agronomy 2020, 10, 1110. [CrossRef] 
12. Li, Z.; Fang, H. Impacts of climate change on water erosion: A review. Earth-Sci. Rev. 2016, 163, 94-117. [CrossRef]

13. Wischmeier, W.H.; Smith, D.D. Predicting Rainfall Erosion Losses-A Guide to Conservation Planning. In Agricultural Handbook; U. S. Department of Agriculture: Hyatsville, MD, USA, 1978; No. 537; p. 58.

14. Renard, K.G.; Foster, G.R.; Weesier, G.A.; Mccool, D.K.; Yoder, D.C. Predicting Soil Erosion by Water: A Guide to Conservation Planning with the Revised Universal Soil Loss Equation (RUSLE); United States Department of Agriculture: Washington, DC, USA, 1997; p. 407.

15. Maqsoom, A.; Aslam, B.; Hassan, U.; Kazmi, Z.A.; Sodangi, M.; Tufail, R.F.; Farooq, D. Geospatial Assessment of Soil Erosion Intensity and Sediment Yield Using the Revised Universal Soil Loss Equation (RUSLE) Model. ISPRS Int. J. Geo-Inf. 2020, 9, 356. [CrossRef]

16. Lense, G.H.E.; Moreira, R.S.; Parreiras, T.C.; Santana, D.B.; Bolello, T.d.M.; Mincato, R.L. Water erosion modeling by the Erosion Potential Method and the Revised Universal Soil Loss Equation: A comparative analysis. Rev. Ambiente Água 2020, 15, e2501. [CrossRef]

17. Efthimiou, N.; Lykoudi, E.; Karavitis, C. Comparative analysis of sediment yield estimations using different empirical soil erosion models. Hydrol. Sci. J. 2017, 62, 2674-2694. [CrossRef]

18. Sakuno, N.R.R.; Guiçardi, A.C.F.; Spalevic, V.; Avanzi, J.C.; Silva, M.L.N.; Mincato, R.L. Adaptation and application of the erosion potential method for tropical soils. Rev. Ciência Agronômica 2020, 51, e20186545. [CrossRef]

19. Balasubramani, K. Estimation of soil erosion in a semi-arid watershed of Tamil Nadu (India) using revised universal soil loss equation (rusle) model through GIS. Model. Earth Syst. Environ. 2015, 1, 10. [CrossRef]

20. Jiang, L.; Yao, Z.; Wu, S.; Wang, R.; Wang, L. Estimation of soil erosion in some sections of Lower Jinsha River based on RUSLE. Nat. Hazards 2015, 76, 1831-1847. [CrossRef]

21. Alewell, C.H.; Borrelli, P.; Meusburger, K.; Panagos, P. Using the USLE: Chances, challenges, and limitations of soil erosion modelling. Int. Soil Water Conserv. Res. 2019, 7, 203-225. [CrossRef]

22. Estimated Soil Loss by Water Erosion by Land Cover Type. 2020. Available online: http:/ / ec.europa.eu/eurostat/data/database (accessed on 20 August 2020).

23. VUPOP 36. Proceedings of Soil Science and Conservation Researcg Institute; Slovak publishing house of agricultural literature: Bratislava, Slovakia, 2014; p. 168. ISBN 978-80-8163-007-1. (In Slovak)

24. Hucko, P. Sediments in the reservoirs in the Slovak Republic. In Proceedings of the Conference Drinking Water; W\&ET Team, Č.: Budějovice, Czech Republic, 2016; pp. 33-44, ISBN 978-80-905238-2-1. (In Slovak).

25. Petrovič, F.; Stranovský, P.; Muchová, Z.; Falt’an, V.; Skokanová, H.; Havlíček, M.; Gabor, M.; Špulerová, J. Landscape-ecological optimization of hydric potential in foothills region with dispersed settlements. A case study of Nova Bosaca, Slovakia. Appl. Ecol. Environ. Res. 2017, 15, 379-400. [CrossRef]

26. Antal, J.; Stred'anský, J.; Stred'anská, A.; Tátošová, L.; Lackóová, L. Soil Protection and Fertilization; SPU: Nitra, Slovakia, 2014; p. 210. ISBN 978-80-552-1205-0. (In Slovak)

27. Act 220/2004 Coll. on the Protection and Use of Agricultural Land and Amending Act no. 245/2003 Coll. on Integrated Prevention and Control of Environmental Pollution and on Amendments to Certain Acts. Available online: https://www. zakonypreludi.sk/zz/2004-220 (accessed on 20 August 2020). (In Slovak).

28. Muchová, Z.; Raškovič, V. Fragmentation of land ownership in Slovakia: Evolution, context, analysis, and possible solutions. Land Use Policy 2020, 95, 104644. [CrossRef]

29. Pagáč, J.; Konc, L.; Mokrá, A. Categorization of the districts of the Slovak Republic in term of fragmentation in land ownership. In SGEM, 1st ed.; STEP92 Technology, 1012 s.; SGEM: Sofia, Bulgaria, 2019; pp. 85-94. ISBN 978-619-7408-86-7.

30. Urban, J.; Hudecová, L'.; Muchová, Z.; Pauditšová, E.; Julény, A.; Uhlík, V. Slovakia. Country of Unknown Owners. Resolution of Land Ownership by Land Consolidation. Slovak Chamber of Land Consolidation; Bratislava, Slovakia, 2019; p. 125. Available online: http://www.kpu.sk/sites/default/files/slovensko_-_krajina_neznamych_vlastnikov_3_sk5.pdf (accessed on 21 March 2020). (In Slovak)

31. Muchová, Z.; Tárniková, M.; Petrovič, F. Elimination of the fragmentation of land ownership as a initiative for positive changes in a country, specific (implemented) example—Vel'ké Vozokany (Slovakia) project area. In SGEM, 1st ed.; STEP92 Technology; SGEM: Sofia, Bulgaria, 2014; pp. 239-246. ISBN 978-619-7105-11-7.

32. Beltramo, R.; Rostagno, A.; Bonadonna, A. Land Consolidation Associations and the Management of Territories in Harsh Italian Environments: A Review. Resources 2018, 7, 19. [CrossRef]

33. Mansberger, R.; Seher, W. Land administration and land consolidation as part of Austrian land management. EU Agrar. Law 2017, 6, 68-76. [CrossRef]

34. Krupowicz, W.; Czarnecka, A.; Grus, M. Implementing crowdsourcing initiatives in land consolidation procedures in Poland. Land Use Policy 2020, 99, 105015. [CrossRef]

35. Jürgenson, E. Land reform, land fragmentation and perspectives for future land consolidation in Estonia. Land Use Policy 2016, 57, 34-43. [CrossRef]

36. Hendricks, A.; Lisec, A. Land consolidation for large-scale infrastructure projects in Germany. Geod. Vestn. 2014, 58, 4668. [CrossRef]

37. Demetriou, D.; Stillwell, J.; See, L.M. Land consolidation in Cyprus: Why is an Integrated Planning and Decision Support System required? Land Use Policy 2012, 29, 131-142. [CrossRef] 
38. Lisec, A.; Primožič, T.; Ferlan, M.; Šumrada, R.; Drobne, S. Land owners' perception of land consolidation and their satisfaction with the results-Slovenian experiences. Land Use Policy 2014, 38, 550-563. [CrossRef]

39. Elvestad, H.E.; Sky, P.K. Efects of Land Consolidation in Norway. Nord. J. Surv. Real Estate Res. 2019, 14, 64-78.

40. Hartvigsen, M. Land consolidation and land banking in Denmark-Tradition, multi-purpose, and perspectives. Dan. J. Geoinform. Land Manag. 2014, 47, 51-73.

41. Sulonen, K.; Kotilainen, S. Lessor's Status in land consolidation in Finland. Nord. J. Surv. Real Estate Res. 2016, 11, 18-36.

42. Janus, J.; Markuszewska, I. Forty years later: Assessment of the long-lasting effectiveness of land consolidation projects. Land Use Policy 2019, 83, 22-31. [CrossRef]

43. Jusková, K.; Muchová, Z. Land consolidation as an instrument for land ownerschip defragmentation in the Czech Republic and Slovakia. In MendelNet, 1st ed.; MendelNet, Mendelova Univerzita: Brno, Czech Republic, 2013; p. 959. ISBN 978-80-7375-908-7.

44. Zoning Plan of the City Nemšová 2018. Available online: https://www.nemsova.sk/na-stiahnutie/subory/7/upn-m-nemsova-zavazna-cistopis.pdf (accessed on 10 June 2020). (In Slovak).

45. Zoning Plan of the Village Horné Srnie 2008. Available online: https://www.hornesrnie.sk/sk/wp-content/subory/2012/10/ Sprievodna_sprava.pdf (accessed on 10 June 2020). (In Slovak).

46. Majský, J.; Mertanová, S.; Hauk, R. Vlára, a Territory of European Importance; State Nature Protection of the Slovak Republic: Banská Bystrica, Slovakia, 2015; ISBN 978-80-89802-47-0. (In Slovak)

47. Janeček, M. Protection of Agricultural Land from Erosion; VÚMOP: Praha, Czech Republic, 2007; p. 76s. ISBN 978-80-254-09732. (In Czech)

48. Janeček, M. Protection of Agricultural Land from Erosion. Methodology; ČZU: Praha, Czech Republic, 2012; ISBN 978-80-87415429. (In Czech)

49. Decree, no. 59/2013 Coll., Amending Decree no. 508/2004 Coll. and Which Implements Act no. 220/2004 Coll. on the Protection and Use of Agricultural Land and Amending Act no. 245/2003 Coll. on Integrated Prevention and Control of Environmental Pollution and on Amendments to Certain Acts. Available online: https://www.slov-lex.sk/pravne-predpisy/SK/ZZ/2013/59/ vyhlasene_znenie.html (accessed on 20 August 2020). (In Slovak).

50. Ilavská, B.; Jambor, P.; Lazúr, R. Identification of Threats to Soil Quality due to Water and Wind Erosion and Proposal of Measures; VÚPOP: Bratislava, Slovakia, 2005; p. 60. (In Slovak)

51. Šurda, P.; Šimonides, I.; Antal, J. A determination of area of potential erosion by geographic information system. J. Environ. Eng. Landsc. Manag. 2007, 15, 144-152. [CrossRef]

52. Alena, F. Determination of Soil Loss by Erosive Runoff for the Design of Erosion Control Measures: Methodological aid; ŠMS: Bratislava, Slovakia, 1986; p. 58. (In Slovak)

53. STN 75 4501:2000: Hydromelioration. Erosion Protection of Agricultural Land. Basic Provisions; Slovak Office of Standards: Metrology and Testing, Bratislava, 2000. (In Slovak)

54. ZBGIS. Available online: https:/ / zbgis.skgeodesy.sk/ (accessed on 15 January 2020).

55. Zhang, Y.; Jin, R.; Zhu, W.; Zhang, D.; Zhang, X. Impacts of Land Use Changes on Wetland Ecosystem Services in the Tumen River Basin. Sustainability 2020, 12, 9821. [CrossRef]

56. Igaz, D.; Bárek, V.; Halaj, P.; Takáč, J.; Čimo, J. A comparison of measured soil moisture with simulated results obtained by selected models for Danubian lowland. Cereal Res. Commun. 2008, 36, 1619-1622.

57. Sumfleth, B.; Majer, S.; Thrän, D. Recent Developments in Low iLUC Policies and Certification in the EU Biobased Economy. Sustainability 2020, 12, 8147. [CrossRef]

58. Csikos, N.; Schwanebeck, M.; Kuhwald, M.; Szilassi, P.; Duttmann, R. Density of Biogas Power Plants as An Indicator of Bioenergy Generated Transformation of Agricultural Landscapes. Sustainability 2020, 11, 2500. [CrossRef]

59. Jurík, L.; Hubačíková, V.; Pokrývková, J. Soil erosion-Environmental and economic context. In Management; Bookman: Prešov, Slovakia, 2018; pp. 625-630. ISBN 978-80-8165-301-8.

60. Heidi, L.; Marianne, P.; Klaus, S. Do farmers care about rented land? A multi-method study on land tenure and soil conservation. Land Use Policy 2019, 82, 228-239.

61. Schwilch, G.; Lemann, T.; Berglund, Ö.; Camarotto, C.; Cerdà, A.; Daliakopoulos, I.N.; Kohnová, S.; Krzeminska, D.; Marañón, T.; Rietra, R.; et al. Assessing Impacts of Soil Management Measures on Ecosystem Services. Sustainability 2020, 10, 4416. [CrossRef]

62. FAO. Available online: http://www.fao.org/home/en/ (accessed on 15 July 2020).

63. Rapsomanikis, G. The Economic Lives of Smallholder Farmers. An Analysis Based on Household Data from Nine Countries; Food and Agriculture Organization of the United Nations (FAO): Rome, Italy, 2015.

64. Azadi, H.; Vanhaute, E.; Janečková, K.; Sklenička, P.; Teklemariam, D.; Feng, L.; Witlox, F. Evolution of land distribution in the context of development theories. Land Use Policy 2020, 97, 104730. [CrossRef]

65. Walmsley, A.; Azadi, H.; Tomeckova, K.; Sklenicka, P. Contrasting effects of land tenure on degradation of Cambisols and Luvisols: The case of Central Bohemia Region in the Czech Republic. Land Use Policy 2020, 99, 104956. [CrossRef]

66. Uchiyama, Y.; Kohsaka, R. Access and Use of Green Areas during the COVID-19 Pandemic: Green Infrastructure Management in the "New Normal". Sustainability 2020, 12, 9842. [CrossRef] 